\title{
ADAPTASI PEMBELAJARAN SENI BUDAYA BERBASIS KOLABORATIF MASYARAKAT PADA MASA DARURAT COVID 19
}

\author{
Ceceng Kosasih \\ SMPN Satu Atap 2 Cikatomas \\ Ce2ng79@gmail.com
}

\begin{abstract}
This article is the result of a study of the learning system developed during the emergency of the COVID-19 pandemic. The concept of collaborative learning with the community is an alternative and is allegedly able to complement the deficiencies in the distance learning process carried out with online, offline or semi-network systems., with various obstacles it faces.
\end{abstract}

Keywords: Learning, collaborative, community

\begin{abstract}
ABSTRAK
Artikel ini merupakan hasil kajian dari sistem pembelajaran yang dikembangkan pada masa darurat pandemi covid 19. konsep pembelajaran berbasis kolaboratif dengan masyarakat merupakan alternative dan disinyalir dapat melengkapi kekurangan-kekurangan pada proses pembelajaran jarak jauh yang dilakukan dengan sistem dalam jaringan, luar jaringan ataupun semi dalam jaringan, dengan berbagai Kendala yang dihadapinya.
\end{abstract}

Kata kunci: Pembelajaran, kolaboratif, masyarakat

\section{A. Pendahuluan}

Sifat pendidikan seni yang multilingual, multidimensi dan multikultural menjadikan peran pendidikan seni menjadi penting dalam upaya pembentukan karakter siswa. (Narawati, 2003) Permasalahan pendidikan seni dan Pembelajarannya menjadi tantangan tersendiri bagi para insan pendidikan khususnya guru sebagai garda terdepan pendidikan. Guru dituntut dapat merancang dan melaksanakan pembelajaran yang sesuai dengan konteks sosial masyarakat dimana para siswanya hidup dan berkembang.

Permasalahan pendidikan seni bertambah berat dengan kehadiran wabah penyakit. Seperti kita ketahui bersama, wabah penyakit yang disebabkan oleh virus yang namanya korona atau lebih dikenal dengan nama covid 19 (coronavirus deaseas) yang berasal dari wuhan cina. pandemi covid 19 meluluh lantahkan sendisendi kehidupan berbangsa dan bernegara. Dampak dari wabah ini tidak hanya menyerang kesehatan fisik semata, namun berdampak luas pada berbagai bidang kehidupan masyarakat, seperti sosial ekonomi, pendidikan dan kebudayaan. Perubahan tatanan kehidupan sosial diberlakukan guna mencegah dan memutus rantai penularan virus ini dengan pemberlakuan aturan protocol kesehatan yang diterapkan pemerintah.

Perubahan tatanan dalam dunia pendidikan seperti tercantum dalam surat edaran kemendikbud dapat dilakukan dengan sistem pembelajaran jarak jauh dalam jaringan, luar jaringan ataupun semi daring tergantung kesiapan dan kondisi sekolah dan orang tua masing-masing. Kalaupun pembelajaran dilakukan dengan sistem luar jaringan/tatap muka, semuanya diatur dengan syarat-syarat yang ketat supaya tidak menimbulkan penyebaran penyakit yang mematikan ini. Dengan perubahan cara belajar di atas, maka para guru dituntut kreatif dan inovatif dalam merancang pembelajaran.

Terkait dengan permasalahan ini, konteks tulisan ini difokuskan pada 
penyelesaian permasalahan di sekolah dalam usaha memacu kemampuan guru menyajikan pelajaran seni budaya secara komprehensif ditengah terjangan badai pandemic covid 19 dengan memanfaatkan berbagai sumber daya yang ada pada masyarakat di sekitar sekolah.

\section{B. Pembahasan}

Pembelajaran di sekolah tidak terlepas dari tiga pilar utama pendidikan, yaitu orang tua, masyarakat, dan Negara (sekolah), Terlebih dalam masa darurat covid 19 seperti sekarang ini, dimana pembelajaran dibatasi dengan pembelajaran jarak jauh guna mencegah dan memutus rantai penyebaran penyakit, maka peran orang tua dan masyarakat menjadi lebih dominan jika dibandingkan dengan pembelajaran pada saat normal.

Pernyataan tersebut memposisikan pendidikan di dalam konteks sosial masyarakat, dan hal ini merupakan penerapan konsep pendidikan yang benar. pendidikan Pendidikan yang benar adalah pendidikan yang hidup dari dan untuk masyarakat. Pendidikan yang berdasar pada masyarakat merupakan bentuk pendidikan yang sebenarnya. Pendidikan akan menjadi terasing dari konteks tujuannya apabila partisipasi masyarakat diabaikan, karena pendidikan tidak mampu menjawab kebutuhan dan kebudayaan yang nyata. (Hasim, 2010)

Dalam masa darurat covid 19 ini, perlu dilakukan kolaborasi dan koordinasi dengan berbagai unsur yang dapat membantu supaya pembelajaran dapat berlangsung tanpa menimbulkan ekses kesehatan dan keselamatan bagi pendidik dan peserta didik. Prinsip keselamatan dan kesehatan peserta didik, pendidik, kepala sekolah dan seluruh warga satuan pendidikan menjadi hal yang utama yang harus dipertimbangkan.

Sejalan dengan pemikiran diatas, maka Pendidikan yang benar adalah pendidikan yang hidup dari dan untuk masyarakat. Pendidikan yang berdasar pada masyarakat merupakan bentuk pendidikan yang sebenarnya. Pendidikan akan menjadi terasing dari konteks tujuannya apabila partisipasi masyarakat diabaikan, karena pendidikan tidak mampu menjawab kebutuhan dan kebudayaan yang nyata.

Pembelajaran berbasis kolaborasi dengan masyarakat (Community Based Learning) menjadi alternatif yang dapat dilakukan dalam pembelajaran seni di tengah masa pandemik seperti sekarang ini, kekhasan pembelajaran seni budaya yang membuat pelajaran seni budaya tidak dapat tergantikan hanya dengan sistem pembelajaran jarak jauh dalam jaringan. Keterbatasan pembelajaran dalam jaringan dilengkapi dengan pembelajaran kolaborasi dengan masyarakat atau kelompok seni yang ada di daerah sekitar tempat tinggal peserta didik.

Melalui konsep ini peserta didik dan guru merupakan unsur pembelajaran yang dapat menciptakan pembelajaran berbasis masyarakat. Para tokoh seni dan masyarakat, komite/pengurus sekolah, orang tua, dan masyarakat merupakan bagian integral dari upaya pengembangan, perencanaan, implementasi, dan penilaian pembelajaran berbasis masyarakat. Kerja sama ini di samping dapat menciptakan keyakinan dan kebersamaan juga dapat menciptakan usaha kolaboratif untuk mengatasi dan menyelesaikan berbagai persoalan. (Poerwati et al., 2018)

Pembelajaran berbasis kolaborasi masyarakat (Community Based Learning) merupakan pembelajaran yang dirancang, dilaksanakan, dinilai, dan dikembangkan oleh sekolah dan masyarakat yang mengarah pada usaha untuk menjawab tantangan dan peluang yang ada di lingkungan masyarakat dengan berorientasi pada masa depan (Poerwati et al., 2018).

Desain model pembelajaran seni budaya berbasis kolaborasi masyarakat diawali dengan kajian teori belajar sebagai teori pendukung model, kondisi faktual pembelajaran seni budaya, dan kondisi siswa saat ini. Berdasarkan hasil kajian tersebut, diperoleh desain awal komponen model, berupa sintax pembelajaran sebagai berikut: 


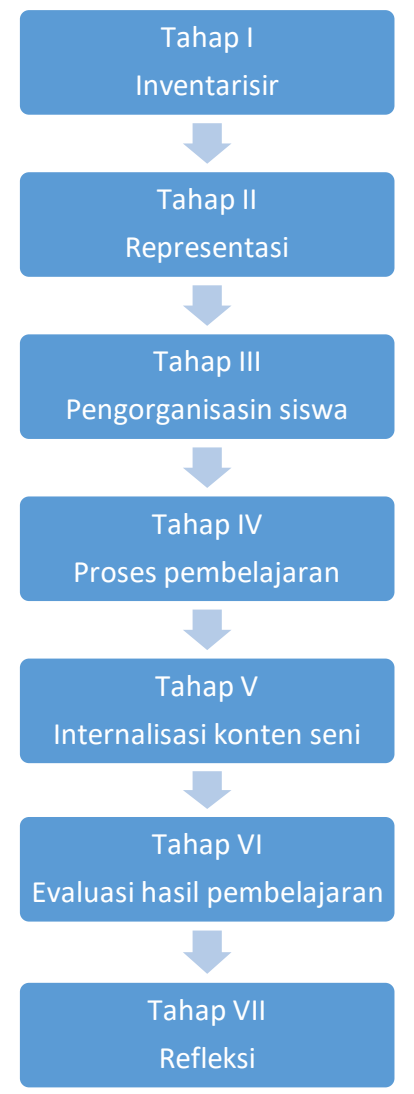

Tahap I : Pada tahap ini guru atau pihak sekolah menginventarisir dan berkoordinasi dengan kelompokkelompok seni yang berkembang pada masyarakat di sekitar tempat tinggal peserta didik

tahap II : Tahapan ini guru merepresentasi pembelajaran yang dapat dilakukan bersama melalui kelompok seni yang ada di masyarakat. Tahap III : Pada tahap ini guru membagi siswa kedalam kelompokkelompok sesuai dengan tempat tinggal

Tahap IV : Tahap ini diisi dengan Proses pembelajaran dan pengembangannya di rumah masyarakat tempat kelompok seni berkembang

Tahap V : Tahapan ini siswa menginternalisasi konten seni budaya yang didapatkan selama proses pembelajaran disertai pengembangannya.

Tahap VI : Evaluasi hasil pembelajaran seni budaya di kelompok-kelompok seni yang ada di masyarakat.
Tahap VII: Refleksi hasil

pembelajaran disertai penghargaan.

Dalam rangka memaksimalkan penerapan model pembelajaran, guru harus membuat rancangan pembelajaran berupa Skenario pembelajaran, Lembar kerja siswa dan tugas-tugas individu/kelompok beserta rubrik penilaian dan materi pendukung lainnya, yang kemudian didiskusikan dan disosialisasikan dengan masyarakat atau kelompok seni yang dijadikan tempat proses pembelajaran.

\section{Simpulan}

Bagaimanapun tantangan dan tingkat kesulitan dalam proses pembelajaran pada masa darurat covid 19, Proses pembelajaran harus tetap berlangsung demi masa depan anak-anak generasi penerus. Pembelajaran jarak jauh bias dilakukan di dalam jaringan dan di luar jaringan. Pembelajaran berbasis kolaborasi masyarakat menjadi alternatif dalam melaksanakan pembelajaran seni budaya yang dapat dilakukan untuk melengkapi kekurangan proses pembelajaran jarak jauh dalam jaringan.

\section{DAFTAR PUSTAKA}

Hasim, M. (2010). Pembelajaran Berbasis Masyarakat di SLTP Alternatif Qaryah Thayyibah Salatiga. Analisa, $17(2)$, 263. https://doi.org/10.18784/analisa.v17i2 .42

Narawati, J. M. \& T. (2003). Seni dan Pendidikan Seni (P. D. R. M. Soedarsono (ed.)). Pusat Penelitian dan Pengembangan Pendidikan Seni Tradisional (P4ST) UPI.

Poerwati, C. E., Pura, U. D., \& Pura, U. D. (2018). Penerapan Model Pembelajaran Masyarakat Belajar Dalam Meningkatkan Kemampuan Berpikir Kritis Mahasiswa Pg-Paud. 2, 76-83. file:///C:/Users/user/Downloads/6072173-1-PB.pdf 